\title{
Civil Society, Referendums and the Media in Turkey: A Comparative Analysis of the Representation of the Referendum Rallies Relating the Constitutional Amendment in 1982 and the Constitutional Amendment Package in 2010
}

Erdal Dağtaş

Assoc. Prof. Dr., Anadolu University Faculty of Communication Sciences

Firat Adiyaman

Research Assistant, Anadolu University Institute of Social Sciences

\section{Doi:10.5901/mjss.2013.v4n9p780}

\section{Abstract}

Civil society generally defines a sphere where groups of people can act without being forced by any source of power. The citizen is one of the most important dynamics of the civil society in that they form a source of power against the state by demanding their rights in the public realm. Citizenship, which is the verbalism of political belonging to the state, is not limited to a legal status in which the individual has a series of specific rights and duties. It is also an expression of the individual's articulation to society and the relationship that they build in the political-social sphere. The media, which should be a democratic institution by essence, is closely related to the civil society. In this day and age most of the political struggle takes place on media. Therefore, the political power always uses the media as an ideological tool. Referendums, on the other hand, are an important constituent in pluralistic democracy. Referendums reflect the political preferences of social groups equally, although in a relative sense. Thus, all different groups can influence the government mechanisms in line with their demands and needs. The role that the media undertakes during the time of referendum, a democratic right for all citizens, is very significant because it is via the media that the information related to the laws or amendments which are put to vote. That is why the analysis and interpretation of media texts that undertake a crucial role in times of referendum is very important. In this context, making a comparative analysis of the selected Turkish media (Cumhuriyet, Hürriyet, Tercüman/Bugün) coverage of 1982 constitutional referendum rallies and 2012 constitutional amendment package referendum rallies, and interpreting them within the framework of civil society discussions makes up the problem of this study. Determining the attitude of Turkish press and whether they had a political bias in 1982 constitutional referendum rallies and 2012 constitutional amendment package referendum rallies forms the purpose of the study. In the study content analysis method has been used. Quantitative distribution and rates of the newspapers' front-page news content and photographs relating with 1982 constitutional referendum and 2012 constitutional amendment package referendum rallies have been determined and compared/contrasted. Besides, the data gathered from the aforementioned newspapers' attitude towards the referendum rallies and thematic analyses of discourses in news texts have been compared/contrasted. One month before 7th October 1982 constitutional referendum and 12th September 2010 constitutional amendment package referendum marks the time limit of the study. Another limitation is regarding the newspapers chosen to represent the Turkish press. Based on their ideological attitudes; Cumhuriyet is chosen to represent national left (Kemalist, statist, secular), Hürriyet to represent liberal and Tercüman/Bugün to represent nationalistic conservative ideology.

Keywords: Civil society, media, citizenship rights, referendum.

\section{Introduction}

Referendums are one of the main features of participatory democracy. Referendums reflect political choices of social groups equally, albeit relatively. By this way, various groups can have their influence on the government. At the time of a referendum, which is a democratic civil right, the role of media is vital because, through media, people are informed about the laws or amendments that will be voted on. Therefore, analysing and interpreting the media texts that undertake a central role at the referendum periods are significant.

In this context, the problem of the study is the comparative analysis and, in the framework of civil society discussions, interpretation of 1982 constitution referendum and 2010 constitutional amendment package referendum rallies' presentation on the newspapers (Cumhuriyet, Hürriyet, Tercüman/Bugün) chosen to represent Turkish press.

The approach of Turkish press in the 1982 constitution referendum rallies and 2010 constitutional amendment 
package referendum rallies, and whether they displayed a political affinity forms the aim of the study. Methodology of the study involves quantitative and qualitative content analysis.

\section{Theorical Framework}

Civil society defines a sphere where human beings can act freely without being pressured by a force (Atabek and Dağtaş, 1998: 1). Contractarian thinkers see civil society as a place where individuals are endowed with a series of rights and responsibilities (Çaha, 1996). Antonio Gramsci distinguishes between civil society and state. However, Gramsci sees civil society as the cultural hegemony that a civil group produces on the whole society (Gramsci, 2009: 19).

Today the concept of civil society is defined with different features in various theories of democracy. Among these theories; (1) Minimal statist civil society, (2) Pluralist civil society, and (3) Participatory civil society models stand out most. Minimal statist civil society and pluralist civil society derive their roots from liberalism, whereas participatory civil society model was inspired by neo-Marxist leftist movement (Atabek and Dağtaş, 1998:41).

Participatory civil society model is fundamentally based on equal participation of various groups in a society in the governing mechanisms. "Political equality", the existential condition of democracy, is not just giving all the citizens the same rights. Democracy is also a means of balancing the social inequalities in the name of moral rights. In fact, within the boundaries of laws, a democratic state should give the most vulnerable citizens the right to disobey the established order where there is inequality, including the state itself (Touraine, 1997:38).

When it first came out, civil society exhibited a structure that integrated with state. Today, however, it appears as a concept that is detached from state, and is one of the main dynamics of democracy. The citizen, who bears a force against state by voicing his/her demands in public spaces, is one the foremost dynamics of civil society. Citizenship, which is the expression of political belonging to state, is not confined to a legal status with a series of privileges and responsibilities. It is also the expression of integrating individual into society and its relationship with political-social space (Üstel, 199:80).

Civil society in Turkey historically has gone through different periods. The history of civil society starts with the political culture of late Ottoman period. In 1923, with the establishment of republic, a need to create a new society and culture emerged. In the literature of statist elitists, state itself was of utmost importance and this concept, not society or civil society, was brought forward (Çaha, 1996: 108). After 1950s, political elitists transformed state-centred order of republican period into a party-centred political order. Until 1950, political elitists who gathered under the roof of Democratic Party (DP) defended -at the state level- the interests of social groups who had fallen down to secondary importance in the face of state interests and had been isolated from the system. Post-1950 Turkish society outlined a society typology that is inclined to differentiation in which each group adds diversity and conflict to the system based on its own interests rather than a harmonised society gathering around common benefits (Çaha, 1996: 124).

In 1980s, two concepts at the heart of discussion agenda in Turkey were civil society and liberalism. Privatisation of state economic enterprises (KIT in Turkish) delegation of authority, funding municipalities, promoting market economy, etc. brought big gains for the civil society front (Çaha, 2007: 228).

Media is closely related to civil society indeed. Today, the attitude of media institutions in forming a public opinion changes the balance of power in the society. Therefore, most of the struggles over political power take place via media. For this reason, governments always use media as an ideological tool. In Turkey, in 1980, when civil society was tried to be removed, although the pressure tools of state were also in use, for propaganda purposes media was again needed. In our contemporary Turkey, media still holds an important role against various hegemonic struggles.

\section{Methodology of the Study and Evaluation of Findings}

Methodology of the study involves quantitative and qualitative content analysis. Quantitative content analysis involves comparing numerical distribution of the news contents and photographs published on front and jump pages of newspapers regarding the rally periods of 1982 Constitution referendum and 2010 Constitutional Amendment package referendum. In qualitative content analysis, the approach of newspapers towards referendum rallies is analysed.

In the study, supportive narration of the news stories concerning the referendum rallies is regarded as "positive". News stories with negative expressions are regarded as "negative". News stories without commentaries are defined as "neutral".

Limitations of the study are as follows: One month before the constitution referendum of 7 November 1982 and constitutional amendment package referendum of 12 September 2012 draws the time limit of the study. In accordance 
with the ideological stances of the newspapers; Cumhuriyet to represent national left (Kemalist, statist, secular), Hürriyet to represent liberal, and Tercüman/Bugün to represent nationalist conservative ideologies have been chosen. The fact that findings of the research can be generalised for only these newspapers makes up another limitation.

\section{The Evaluation of the News in the Newspapers}

Kenan Evren himself, the president in office at the time, led the referendum rallies that were held before 7 November 1982. Hence, there were 40 news articles about the rallies led by Kenan Evren in the newspapers, which are the unit of analysis. It was found out that 14 news stories were made about the rallies in Hürriyet and Tercüman. 12 news stories in the newspapers were directly about the rallies. The remaining 2 news stories covered information about the rallies, which were previously announced.

The news stories included topics such as the information given directly by Kenan Evren about the new constitution, the indoctrinations which were given to the public and political instability. It can be said that Kenan Evren's words formed the basis of headlines, spots and news reports. The language used in all three newspapers is quite similar. In addition to these similarities, it is seen that all three newspapers placed Kenan Evren's words in the base of news reports directly and indirectly.

Table 1: The Quantitative Distribution of Referendum News Articles in Newspapers

\begin{tabular}{|c|c|c|c|c|c|}
\hline \multicolumn{2}{|c|}{1982 Period Analysis Newspapers } & \multicolumn{2}{c|}{ 2010 Period Analysis Newspapers } \\
\hline Newspapers & $\begin{array}{c}\text { Frequency } \\
\text { Number }\end{array}$ & $\begin{array}{c}\text { Frequency } \\
\text { Rates } \\
\%\end{array}$ & Newspapers & $\begin{array}{c}\text { Frequency } \\
\text { Number }\end{array}$ & $\begin{array}{c}\text { Frequency } \\
\text { Rates } \%\end{array}$ \\
\hline Cumhuriyet & 12 & 30 & Bugün & 19 & 20 \\
\hline Hürriyet & 14 & 35 & Cumhuriyet & 33 & 34.73 \\
\hline Tercüman & 14 & 35 & Hürriyet & 43 & 45.27 \\
\hline Total & 40 & 100 & Total & 95 & 100 \\
\hline
\end{tabular}

The polemics of the political figures about the agenda and the mutual accusations among politicians appeared in the news about the referendum rallies that were held before 12 September 2010.

33 news stories were published in Cumhuriyet related to the referendum rallies one month before 12 September 2010. 12 of these were about the rallies held by CHP (Republican People's Party), 9 of them were about the rallies held by AKP (Justice and Development Party), 4 of them were about the rallies held by MHP (Nationalist Movement Party) and 1 was about the rallies held by BDP (Democracy and Peace Party). In the rest of the news stories, some general information about referendum rallies was covered.

It was found out that 43 news articles were made in total about the referendums conducted before 12 September 2010 in Hürriyet. The distribution of the news was as follows: AKP: 21, CHP: 14, MHP: 6, BDP: 1. In the news concerning the rallies, the mutual accusations made by politicians got more coverage than the content of the constitutional amendment package.

It is seen that 19 news stories were published about the referendums held before 12 September 2010 in Bugün. Compared to Cumhuriyet and Hürriyet, Bugün published fewer news stories about the referendum rallies. The distribution of the news is as follows: AKP: 11, CHP: 7, MHP: 1. The significant statements uttered by the politicians were framed in the headlines.

\section{The Evaluation of the News Reflected in Headlines and Subheadings}

It is seen that many of the referendums that were held before 7 November 1982 made the headlines. 8 news stories made the headlines in Cumhuriyet, 7 news stories in Hürriyet and 10 in Tercüman. It can be stated that because the political circumstances of the time were oppressive, the referendum news stories made the headlines. On the other hand, the articles about the rallies were not covered in the subheadings. All three newspapers placed emphasis on the rallies held by Kenan Evren and covered them in the headlines. The news, spots, and the headlines were directly or indirectly associated with the words of Kenan Evren and emphasis was laid on the messages to be given to the public. 
Table 2: The Quantitative Distribution of the Referendum News in the Headlines and Subheadings

\begin{tabular}{|c|c|c|c|c|c|c|c|c|c|}
\hline \multicolumn{5}{|c|}{1982 Analysis Newspapers } & \multicolumn{5}{|c|}{2010 Analysis Newspapers } \\
\hline \multirow[b]{2}{*}{ Newspapers } & \multicolumn{2}{|c|}{ Headline } & \multicolumn{2}{|c|}{ Subheading } & \multirow[b]{2}{*}{ Newspapers } & \multicolumn{2}{|c|}{ Headline } & \multicolumn{2}{|c|}{ Subheading } \\
\hline & $\begin{array}{l}\text { Freq. } \\
\text { Number }\end{array}$ & $\begin{array}{c}\text { Freq. Rate } \\
\%\end{array}$ & \begin{tabular}{|c|} 
Freq. \\
Number
\end{tabular} & $\begin{array}{c}\text { Freq. Rate } \\
\%\end{array}$ & & $\begin{array}{c}\text { Freq. } \\
\text { Number }\end{array}$ & $\begin{array}{c}\text { Freq. Rate } \\
\%\end{array}$ & $\begin{array}{l}\text { Freq. } \\
\text { Number }\end{array}$ & $\begin{array}{c}\text { Freq. Rate } \\
\%\end{array}$ \\
\hline Cumhuriyet & 8 & 32 & - & - & Bugün & - & - & - & - \\
\hline Hürriyet & 7 & 28 & - & - & Cumhuriyet & 1 & 100 & - & - \\
\hline Tercüman & 10 & 40 & - & - & Hürriyet & - & - & - & - \\
\hline Total & 25 & 100 & - & - & Total & 1 & 100 & - & - \\
\hline
\end{tabular}

When we take a look at the rallies held in 2010, we see almost no news that hit the headlines or subheadings. Only Cumhuriyet covered 1 news story about the rallies. Hürriyet and Bugün did not present the news about the referendum rallies in the headlines or subheadings.

\section{The Evaluation of the Photos in the Newspapers}

During the 1982 referendum period, 6 photos were used about the news stories on the referendum rallies in Cumhuriyet. There is only 1 photo of Kenan Evren, who is going on with the rallies, together with the public. A little girl is seen in the photo giving flowers to Kenan Evren.

Table 3: The Quantitative Distribution of the Referendum Photos in Newspapers

\begin{tabular}{|c|c|c|c|c|}
\hline \multicolumn{2}{|c|}{ Newspapers } & Frequency Number & Frequency Rate $\%$ & Total \\
\hline \multirow{3}{*}{1982} & Cumhuriyet & 6 & 30 & 6 \\
\cline { 2 - 5 } & Hürriyet & 4 & 20 & 4 \\
\cline { 2 - 5 } & Tercüman & 10 & 50 & 10 \\
\hline \multirow{3}{*}{2010} & Total & 20 & 100 & 20 \\
\cline { 2 - 5 } & Bugün & 30 & 17.05 & 30 \\
\cline { 2 - 5 } & Cumhuriyet & 44 & 25 & 44 \\
\hline \multicolumn{2}{|c|}{ Hürriyet } & 102 & 57.95 & 102 \\
\hline
\end{tabular}

It appears that Tercüman made use of more photos compared to other newspapers. Tercüman used 10 photos in total. The element that stands out the most is that the 4 photos are of large masses of people who took part in the rallies. Hürriyet used fewer photos in comparison with the other newspapers. It can be stated that Hürriyet used a fewer number of photos compared to the news stories it covered. In one of the photos Kenan Evren is seen together with the public.

In 2010 period, Cumhuriyet used 44 photos of referendum rallies. Distribution of photographs by parties is follows: CHP: 25, AKP: 14, MHP:3, BDP:1. Cumhuriyet put more emphasis on CHP referendum rallies. Photos showing Kemal Kılıçdaroğlu addressing and greeting the people were frequently used. In these photos Kılıçdaroğlu is smiling and he is depicted as a confident man. A majority of the remaining photos include rally images. Cumhuriyet did not cover rallies of MHP and BDP very much. In this context, Cumhuriyet did not treat BDP and MHP equally compared to other parties on the subject of photographs.

Bugün appears to have used fewer photos in 2010 period. In total 30 photos were used for referendum rallies. Distribution of photographs by parties is follows: AKP: 17, CHP: 12, Grey Wolves: 1. Bugün mostly used photos showing Prime Minister Recep Tayyip Erdoğan greeting the crowds. A majority of the other photos shows Erdoğan addressing the people. In these photos, Erdoğan appears to be one with the masses. Bugün used fewer photos of CHP rallies compared to those of AKP's.

With 102 photos Hürriyet had the biggest number of photos covering 2010 referendum rallies. Distribution of photographs by parties is follows: CHP: 42, AKP: 40, MHP: 18, BDP: 2. A large majority of the photos about CHP that Hürriyet used showed the crowds in the rallies. People with flags in their hands were shown; photos with bigger crowds were particularly chosen. In the other photos CHP leader is smiling and looks confident.

Hürriyet dedicated a majority of its AKP referendum photos to Recep Tayyip Erdoğan. In most of the photos Erdoğan is addressing the masses. The photos are giving Erdoğan a positive image. He is smiling and looks determined. The rest of the photos are colourful depictions of rally grounds, which show people holding "yes" banners. Compared to 
other newspapers Hürriyet used more photos of MHP rallies. In the photos, Devlet Bahçeli seems to have a harsh expression on his face while addressing the people. In only one of the photos Bahçeli is seen smiling.

\section{The Evaluation of the Referendum News Stories Regarding the Other Political Parties and Civil Society Organizations}

Table 4: Quantitative Distribution of 1982 Constitution Referendum News Stories about the Civil Society Organisations Setting the Agenda

\begin{tabular}{|c|c|c|c|}
\hline Newspapers & Frequency Number & Frequency Rate $\%$ & Total \\
\hline Cumhuriyet & 4 & 66 & 4 \\
\hline Hürriyet & 1 & 17 & 1 \\
\hline Tercüman & 1 & 17 & 1 \\
\hline Total & 6 & 100 & 6 \\
\hline
\end{tabular}

The opinions of civil society organisations on the Constitutional referendum were almost never covered in the news stories before 7 November 1982. 1 news article in Cumhuriyet was about the thoughts of a constitution committee member. One of the other articles was regarded as negative since "no" campaign was prohibited. In the article with the following headline "50 arrested for anti-constitution campaign" (Cumhuriyet, 28 October 1982: 1), the people arrested were described as organisation members. The same story was also regarded as negative in Tercüman and Hürriyet newspapers with similar discourses. Hürriyet identified the people holding the "no" campaign as militants and extremist group members.

Table 5: Quantitative Distribution of 2010 Constitution Amendment Referendum News Stories about the Civil Society Organisations and Other Political Parties Setting the Agenda

\begin{tabular}{|c|c|c|c|}
\hline Newspapers & Frequency Number & Frequency Rate $\%$ & Total \\
\hline Bugün & 40 & 40 & 40 \\
\hline Cumhuriyet & 55 & 54 & 55 \\
\hline Hürriyet & 6 & 6 & 6 \\
\hline Total & 101 & 100 & 101 \\
\hline
\end{tabular}

Cumhuriyet published 55 news stories about the civil society organisations and political parties expressing their opinions on the 12 September 2010 Constitutional Amendment Package referendum. 38 of the articles included ideas of civil society organisations concerning the constitution. Associations, unions, guilds, artists and academicians were in these civil society organisations. Cumhuriyet particularly had civil society organisations that propounded "no" vote regarding the constitution. With 12 news articles, Cumhuriyet featured BDP's ideas the most among political parties. BDP rallies were not covered in articles; however their reflections on the constitution were featured in Cumhuriyet. Distribution of news articles about other parties is as follows: Felicity Party: 2, Communist Party of Turkey: 1, Rights and Equality Party: 1, New Party: 1.

Hürriyet featured 6 articles on this issue. In this context, Hürriyet ignored different opinions about constitution; and mostly reflected the thoughts of business world. Turkish Exporters' Assembly, Ankara Chamber of Commerce, Right and Work Union, Turkish Employers Union, which announced they would vote "Yes", were mentioned in Hürriyet news.

Bugün's attitude was similar to that of Cumhuriyet. Cumhuriyet put more emphasis on "no" vote whereas Bugün made stories about the civil society organisations announcing their "yes" votes. Bugün featured 40 articles covering the opinions of groups about the constitution. 22 of these are about civil society organisations; 18 about political parties. The newspaper highlighted "yes" statements rather than rally stories. In the articles covering constitution amendment package, the political parties seemed to have positive opinions in Bugün. The statements made by political parties appear to support the amendment: Great Union Party: 5, Democratic Party: 9, Felicity Party: 1, Nationalist and Conservative Party: 1, Equality and Democracy Party:1, Revolutionary Socialist Workers' Party: 1.

\section{Evaluation of Newspapers' Approaches towards Referendum Rallies}

The framework of news determines qualities of news. If the story carries Five Ws and one $\mathrm{H}$ principle and the essence of 
the story is given, this story is neutral. Otherwise, "highlighting" and "framing" elements will be integrated into the story. Thus, news text will be enclosed in favour of or against the message aimed at the story. This points out the positivity or negativity of the news story.

In this context, most of the news stories covering the 1982 Constitution referendum phase are positive. Cumhuriyet, Hürriyet and Tercüman reflected a large majority of the stories as positive. All three newspapers presented Kenan Evren's speeches as positive. The number of positive stories in the newspapers is 30 . On the other hand, the newspapers did not cover any negative stories about the rallies. Lastly, only 10 stories were identified as neutral in total.

Table 6: The Approach of Newspapers towards Referendum Rallies: Quantitative Distribution of Positive, Negative and Neutral News Stories

\begin{tabular}{|c|c|c|c|c|c|c|c|c|c|}
\hline \multirow{2}{*}{\multicolumn{2}{|c|}{ Newspapers }} & \multicolumn{2}{|c|}{ Positive } & \multicolumn{2}{|c|}{ Negative } & \multicolumn{2}{|c|}{ Neutral } & \multicolumn{2}{|c|}{ Total } \\
\hline & & \multirow{2}{*}{$\begin{array}{c}\text { Freq. } \\
\text { Number }\end{array}$} & \multirow{2}{*}{\begin{tabular}{|c|}
$\begin{array}{c}\text { Freq. Rate } \\
\%\end{array}$ \\
30 \\
\end{tabular}} & \multirow{2}{*}{$\begin{array}{c}\text { Freq. } \\
\text { Number } \\
-\end{array}$} & \multirow{2}{*}{\begin{tabular}{|c|}
$\begin{array}{c}\text { Freq. Rate } \\
\%\end{array}$ \\
- \\
\end{tabular}} & \multirow{2}{*}{$\begin{array}{c}\begin{array}{c}\text { Freq. } \\
\text { Number }\end{array} \\
3\end{array}$} & \multirow{2}{*}{$\begin{array}{c}\text { Freq. Rate } \\
\% \\
30 \\
\end{array}$} & \multirow{2}{*}{$\begin{array}{c}\begin{array}{c}\text { Freq. } \\
\text { Number }\end{array} \\
12\end{array}$} & \multirow{2}{*}{$\begin{array}{c}\text { Freq. Rate } \\
\% \\
30 \\
\end{array}$} \\
\hline \multirow{3}{*}{1982} & Cumhuriyet & & & & & & & & \\
\hline & Hürriyet & 10 & 33 & - & - & 4 & 40 & 14 & 35 \\
\hline & Tercüman & 11 & 37 & - & - & 3 & 30 & 14 & 35 \\
\hline \multicolumn{2}{|r|}{ Total } & 30 & 100 & - & - & 10 & 100 & 40 & 100 \\
\hline \multirow{3}{*}{2010} & Bugün & 12 & 19 & - & - & 7 & 22 & 19 & 20 \\
\hline & Cumhuriyet & 20 & 32 & - & - & 13 & 40 & 33 & 35 \\
\hline & Hürriyet & 31 & 49 & - & - & 12 & 38 & 43 & 45 \\
\hline \multicolumn{2}{|r|}{ Total } & 63 & 100 & - & - & 32 & 100 & 95 & 100 \\
\hline
\end{tabular}

Looking at 2010 Constitutional Amendment referendum phase, we can say that although the newspapers qualitatively did not treat political parties' approaches towards referendum equally, they were fair quantitatively. The newspapers reflected messages positively as there were polemics among all political parties in their referendum rallies. In other words, the newspapers had an equal stance to all the parties. For instance, despite having opposite ideologies, Cumhuriyet and Bugün reflected AKP's and CHP's rallies as positive. The newspapers covered 63 stories in total, and 32 neutral ones. Similar to 1982 referendum phase, during this period, newspapers did not publish any "negative" news articles.

\section{Conclusion}

It could be argued that newspapers (Cumhuriyet, Hürriyet and Tercüman) were under pressure in 1982 referendum rallies. The newspapers reflected Kenan Evren's thoughts about the constitution positively by giving them in headlines and subheads. Evren frequently emphasised that the new constitution was democratic; and the newspapers directly used this discourse in their headlines. In addition to this, Evren's remarks on the chaotic atmosphere of pre-12 September 1982 were given in the newspapers. These fear-oriented news items could have affected people's political choices negatively. In 1982 period, identifying people holding "no" campaign as militants had a negative aspect in terms of civil society dynamics.

The approaches of analysed newspapers towards 2010 Constitutional Amendment package are as follows: Taking Cumhuriyet and Bugün's approaches into account, Cumhuriyet covered articles only about the civil society organisations with "no" vote; Bugün mostly covered articles about the civil society organisations with "yes" vote. When compared to 1982 period, having civil society organisations' voices in the newspapers could be seen as positive. Nevertheless, the fact that Bugün and Cumhuriyet were not able to make different voices heard suggests that those newspapers exhibited a politically biased attitude.

Hürriyet, ignoring the other civil society organisations, reflected only the opinions of business world. Bugün showed affinity to AKP by keeping "yes" vote on the agenda while Cumhuriyet showed affinity to CHP by focusing on the "no" vote. Hürriyet treated "yes" and "no" votes equally. However, it did not publish the statements of civil society organisations very often. Finally, in 2010 period, all three newspapers put importance on two major parties' rallies. Mostly stories covering the rallies of AKP and CHP were represented in the newspapers. 


\section{References}

Atabek, Nejdet ve Erdal Dağtaş (1998). Kamuoyu ve Illetişim. Eskişehir: Anadolu Üniversitesi Yayınları.

Bugün Gazetesi. (12 Ağustos-12 Eylül 2010).

Cumhuriyet Gazetesi. (7 Ekim-7 Kasım 1982 ve 12 Ağustos-12 Eylül 2010).

Çaha, Ömer (1996). Türkiye'de Sivil Toplum ve Kadın. Konya: Vadi Yayınları.

Çaha, Ömer (2007). Aşkın Devletten Sivil Topluma. İstanbul: Plato Film Yayınları.

Gramsci, Antonio (2009). Hapishane Defterleri. Çev. Kenan Somer. Ankara: Aşina Kitaplar.

Hürriyet Gazetesi. (7 Ekim-7 Kasım 1982 ve 12 Ağustos-12 Eylül 2010).

Tercüman Gazetesi. (7 Ekim-7 Kasım 1982).

Touraine, Alain (1997). Demokrasi Nedir? Çev: Olcay Kunal. İstanbul: Yapı Kredi Yayınları.

Üstel, Füsun (1999). Yurttaşlık ve Demokrasi. Ankara: Dost Kitabevi Yayınları. 